Thus modern technical resources are being used to make exhibits educational and to stimulate interest in natural history. But what about the many specimens of which the rarity, obscure character, or specialized interest do not make it feasible to give them expensive display space ? How are these to be made available to the serious student? What is to happen to the many specimens eluttering up museum cases when these are relegated to storage cabinets ?

It is probable that the answer will be found in the development of reference museums. We have all admired the efficient organization of libraries, where staffs have been trained in the cataloguing and care of books, and their preservation in fire-resisting structures. The huge bulk of accumulated natural history specimens in many of the older museums presents a storage problem. With the gradual extinction of many species of wild life, the growing scarcity of others, and the increasing difficulties of collecting, it is essential that what we already have be assured permanent preservation and greater accessibility to students.

Such collections could be compactly stored in metal cabinets in vermin-proof, fire-resisting library. stack-like structures. Specially trained curators could receive, prepare, catalogue, place and care for the specimens received by the museum. The distribution of specimens to research workers in their own and to other institutions, and of loan collections of duplicates to schools, would be in their hands. No small part of their activity would be to bring out of the stack, for examination at close hand, any specimen desired by a serious student.

An experiment in this direction will soon be made by the Mineralogical Department of the Academy. Visitors will be advised that any specimens they desire to see, if not on exhibition, will be placed by a member of the staff in a special, well-lighted case for their examination.

\title{
The German North Atlantic Expedition*
}

$\mathrm{H}^{2}$ AVING almost completed their examination of the data brought home from the South Atlantic Ocean by the Meteor in 1925-27, German oceanographers have set out to make a thorough investigation of the North Atlantic, and as the result of a conference between the Commander-inChief of the Navy, the council of the Deutschen Wissenschaft and the director of the Institut für Meereskunde, the German North Atlantic Expedition has been organized.

The plan of the new expedition is to complete the network of modern oceanographical observations over the Atlantic Ocean, linking up the work of the Meteor in the south with her subsequent investigations in Iceland and Greenland waters, and with the work of the American Marion and Atlantis expeditions in the Davis Strait and the western North Atlantic. The area to be covered extends from $15^{\circ} \mathrm{N}$. to $64^{\circ} \mathrm{N}$. between the west coast of Europe and Africa and a line from the West Indies to Nova Scotia.

The main objects are the study of the physicochemical structure of the sea, and meteorology. It is hoped that a large number of scientific and practical problems, many of them connected with the Gulf Stream, will be solved, and Prof. A. Defant, who is directing the work, is confident that information likely to be of material assistance in long-range weather forecasting will be obtained.

The Meteor, now re-engined as a motor-vessel with a cruising radius of 9,000 miles at an average speed of 12 knots, is to be used, and the Institut für Meereskunde, the Deutsche Seewarte, the Marine Observatories of Wilhelmshaven and Kiel, and the State Meteorological Department, are co-operating with the Navy. The whole project is not to be accomplished in one commission, but by a number of shorter voyages.

The first voyage, partly a trial cruise, and mainly

- "Bericht über den ersten Teil der Deutschen Nordatlantischen Expedition des Forschungs- und Vermessungsschiffes Meteor, Februar bis Mai, 1937", Von A. Defant. Sonderausgabe aus den Sitzungsberichten der Preussischen Akademie der Wissenschaften, Phys.-math. Klasse, 19 (1937). an addition to the original programme, was started in February and completed in May of last year. The region from $10^{\circ} \mathrm{N}$. to $28^{\circ} \mathrm{N}$. between the African coast and $30^{\circ} \mathrm{W}$. was examined; about seventy stations were worked at 60 -mile intervals on six east-to-west lines, half of them falling between the African coast and the Canary and Cape Verde Islands. At each of the inshore stations hourly observations were made over a period of 60 hours, and one series of current observations over a period of 48 hours was made with the ship anchored in deep water. Six oceanographers, two meteorologists and two magneticians were carried, and the officers and crew numbered 121 .

Only a very preliminary account of the results is available, but it is clear that much important information has been gained. The whole of the coastline of this part of Africa is marked by upwelling, and although the water comes to the surface from relatively shallow depths, the surface temperatures may be $5^{\circ}$ or $6^{\circ} \mathrm{C}$. colder than those farther offshore. The region also has a rich plankton population. The continuous hourly observations reveal changes of very short period, and show that the conditions in the thermocline at a depth of 25-60 metres respond very quickly to changes at the surface. The chemical work included determinations of silica, phosphate and nitrite.

A large number of observations were made on the upper-air currents, 209 balloons being followed by the new radio-ranging method, which seems much better adapted for work in an unsteady ship than the usual theodolite method. The nautical staff carried out an extensive programme of echo-sounding, and made researches into the reliability of modern instruments and methods of fixing positions at sea. Magnetic observations were made in the Canary and Cape Verde Islands.

During the three and a half months voyage, much was accomplished, and it is evident that the investigation of the greater part of the North Atlantic Ocean by similar methods will produce most important results.
G. E. R. D. 